\title{
Die outomatiese oprigting van 'n kabelgesteunde V-vormige kragtoevoertoring: 'n Gevallestudie
}

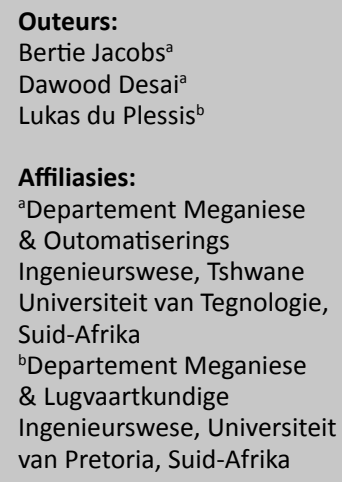

Korresponderende outeur: Bertie Jacobs

E-pos:

bertie.jacobs@eskom.co.za

Datums:

Ontvang: $\quad 17 / 07 / 19$

Aanvaar: $\quad 30 / 10 / 20$

Gepubliseer: 25/11/20

Hoe om hierdie artikel aan te haal:

Bertie Jacobs, Dawood Desai, Lukas du Plessis, Die outomatiese oprigting van' $n$ kabelgesteunde V-vormige kragtoevoertoring: ' $n$ Gevallestudie, Suid-Afrikaanse Tydskrif vir Natuurwetenskap en Tegnologie 39(1) (2020). https://doi.org/10.36303/ SATNT.2020.39.1.732

An English copy of this paper is available online at http://www.satnt.ac.za/ index.php/satnt/article/ view/732

\section{Kopiereg:}

(c) 2020. Authors.

Licensee: Die SuidAfrikaanse Akademie vir Wetenskap en Kuns. Hierdie werk is onder die Creative Commons Attribution License gelisensieer.
Die konstruksie van oorhoofse kraglyne, en veral dié wat as "ekstra hoë spanning" gekategoriseer word, is 'n duur besigheid. Met die oprigting van torings wat die geleiers ondersteun het mobiele hyskrane 'n dominante stuk toerusting geword. Alhoewel hierdie metode relatief vinnig is, kom dit teen 'n baie hoë prys. Daarom sal alternatiewe, goedkoper konstruksiemetodes verseker baie meer aantreklik lyk vir die kontrakteurs wie verantwoordelik dit is vir sodanige konstruksie. Hierdie artikel ondersoek alternatiewe opsies om oorhoofse kraglyntorings op te rig. Klem word gelê op die gebruik van nutspale ('gin poles') en wen-asse ('winches') vir die oprigting van die tipe 520B kabelgesteunde V-toring sodat mobiele hyskrane heeltemal uitgeskakel kan word. Die werk wat hier aangebied word, stel ook voor dat 'n lugkussing as 'n outomatiese metode gebruik kan word om die 520B kabelgesteunde V-torings op te lig.

Sleutelwoorde: Nutspale, kabelgesteunde V-toring, mobiele hyskrane, wen-as, lugkussings

Novel autonomous lifting of a guyed V-tower: A case study: The construction of overhead power lines in the Extra High Voltage category is a costly business. When erecting towers that support the conductors, mobile cranes have become the dominant piece of equipment to erect these towers. Although relatively quick, these mobile cranes do come at a cost and alternative erection methods will be very attractive for contractors responsible for construction. This paper investigates alternative options to erect overhead power line towers with specific emphasis on the use of gin poles and winches for the erection of the type 520B guyed V-tower thereby eliminating mobile cranes. The work presented here also proposes the use of novel methods like air cushions and a degree of automation to lift these guyed V-towers autonomously. Scale modelling is used to confirm experimental findings of the study.

Keywords: gin poles, guyed V-tower, mobile cranes, overhead power lines, winches, lifting air cushions

\section{Inleiding}

Kontrakteurs en kragvoorsieners wat verantwoordelik is vir die oprigting van oorhoofse kraglyne (wat wissel van $132 \mathrm{kV}$ tot $765 \mathrm{kV}$ ) en veral kraglyne in die EHS (ekstra hoë spanning) kategorie van tussen $400 \mathrm{kV}$ en $765 \mathrm{kV}$, gebruik normaalweg mobiele hyskrane om die torings op te rig wat die geleiers ondersteun. Kraangroottes wissel van 70 ton kapasiteit tot 250 ton, afhangende van die lynspanning en daaropvolgende toringgrootte (massa en hoogte). Vanweë die hoogte van die torings is 'n kraan met groter kapasiteit dikwels nodig om die vereiste hoogte te bereik sonder dat die kraan tot sy uiterste hefvermoë benut word. Dit, op sy beurt, voeg onnodige koste toe tot die projek, veral in ag genome die relatiewe lae massa van die toring wat gelig word. Aangesien die kostemodel van mobiele hyskrane sodanig is dat ' $n$ fooi gehef word, ongeag of die hyskraan gebruik word al dan nie vir die gegewe huurperiode, is dit dus duidelik dat, indien alternatiewe oprigtingsmetodes, wat mobiele hyskrane uitskakel, gevind kan word, dit moontlik groot kostebesparings tot gevolg kan hê. Selfs as mobiele hyskrane besit word, is hulle onderhouds- en bedryfskoste gewoonlik die hoogste in vergelyking met ander konstruksietoerusting wat benodig word vir die bou van oorhoofse kraglyne. Hierdie studie stel sulke alternatiewe oprigtingsmetodes voor. 


\section{Huidige konstruksiepraktyke}

In Suid-Afrika bestaan die meeste van die $31000 \mathrm{~km}$ (Eskom, 2016) oorhoofse kraglyne wat gebou word in die $132 \mathrm{kV}$ tot $765 \mathrm{kV}$ kategorie, uit hoekyster-staaltorings wat gebruik word om die geleierbundels te ondersteun. Die hoekyster-staaltorings kan verdeel word in ankertorings en hangtorings. Die hangtorings kan verder verdeel word in selfondersteunde- en kabelgesteunde tipe hangtorings. Hangtorings word in groter hoeveelhede gebruik vir 'n kraglyn en dit is met die oprigting van sodanige torings waar die grootste potensiële besparingsvoordeel realiseer kan word. Hierdie studie fokus op die oprigting van die hoogste van sy soort, 520B-tipe kabelgesteunde V-toring wat geskik is vir $400 \mathrm{kV}$-toepassings. Sulke torings word wyd deur Eskom, die kragvoorsiener in Suid-Afrika, gebruik. 'n Voorbeeld van so toring kan in Figuur 1 gesien word.

Verskillende oprigtingsmetodes word huidiglik gebruik (Kiessling et al.,2003) om 'n tipe 520B hangtoring op te lig, waarvan die mees algemeenste die gebruik van 'n groot genoeg mobiele hyskraan behels, wat die toring eenvoudig van sy aanvanklike horisontale posisie tot sy finale regop posisie ophys en plaas. Voordat oprigting begin, word die torings eers aanmekaargesit in lyn met die rigting waarin die oorhoofse lyn gebou word en met die bokant van die toring naby die toringfondasie. Die hyskraan word geposisioneer naby die toringfondasie waar die toringbene tydelik aan mekaar gebind word en die onderpunt van die

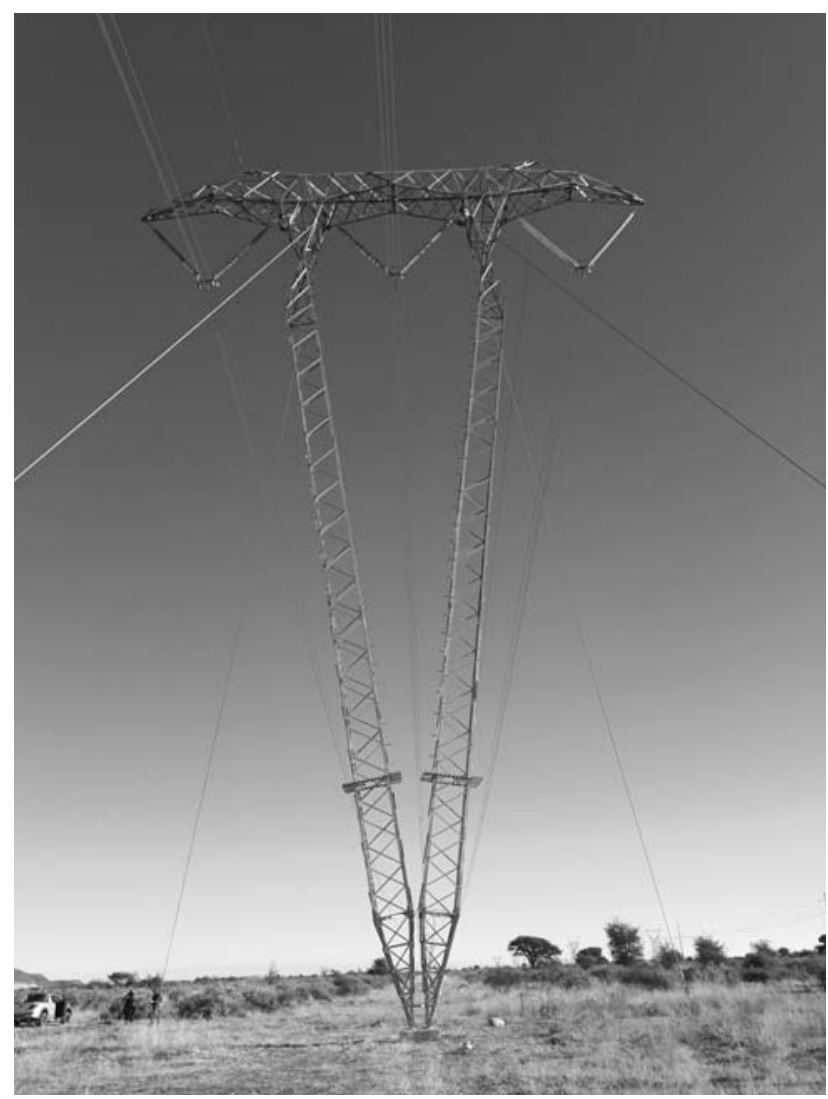

FIGUUR 1: 'n Tipe 520B kabelgesteunde V-toring. bene op 'n sleë of mobiele trollie vasgemaak word. Terwyl die toring deur die hyskraan gelig word, beweeg die onderkant van die toring saam met die sleë of mobiele trollie nader aan die toringfondasie. Sodra die toring regop staan word dit op sy fondasie geplaas sodat die permanente ankertoue aan hulle ankers vasgebind en styfgetrek kan word. Die toring word nagegaan om seker te maak dat dit regop staan en dan word die ankertoue tot op hulle korrekte spanning verstel. Werkers kan dan na die bokant van die toring klim waarna die hyskraan ontkoppel word en die werkspan met die toerusting na die volgende toringposisie verskuif word. Vordering op die konstruksieterrein is dus afhanklik van die aantal mobiele hyskrane wat ontplooi kan word asook die tyd wat dit neem vir die hyskraan om van een toringposisie na die volgende te beweeg. Dikwels is padtoestande baie sleg en hyskrane wat vasval a.g.v. hulle grootte en massa is 'n algemene probleem wat vertragings veroorsaak met gepaardgaande finansiële verliese. Dit is dus duidelik dat, indien alternatiewe toerusting gebruik kan word om hierdie tipe hangtorings op te rig, en sulke toerusting goedkoop gedupliseer en maklik verskuif kan word, dit groter produktiwiteit en beduidende kostebesparings teweeg kan bring. Hierdie studie wat sulke alternatiewe oprigtingsmetodes vir hangtorings ondersoek, is dus geregverdig.

\section{'n Alternatiewe Oprigtingsmetode}

Deur van nutspale en wen-aste in 'n spesifieke uitleg gebruik te maak, stel Figure 2 en 3 so 'n alternatief voor. Kortliks behels dit die volgende orde van oprigting: Die 520B tipe hangtoring word volkome op die grond en in-lyn met die rigting van die oorhoofse lyn aanmekaar gesit maar met die onderkant van die toring naby sy fondasie. 'n Skarniermeganisme met geskikte domkragte word nou oor die toringfondasie geplaas en die onderkant van die toring aan die skarniermeganisme geheg. Geskikte tydelike ankers word gebruik om die skarniermeganisme behoorlik vas te anker. Die lengte en posisie van die nutspaal sowel as die posisie van die wen-aste word bepaal met behulp van 'n numeriese program, wat die posisie en grootte van toerusting verifieer. Enige tydelike bykomende ankerpunte word ook nou in posisie gebring. Die nodige toue wat gebruik word tydens oprigting, sowel as elektroniese sensorssooslasselle, inklinasiemetersenversnellingssensors word aan 'n beheertoestel gekoppel. Die optrek van die toring kan nou deur die hoof wen-as begin word terwyl stabiliteit deur sekondêre wen-aste verseker word, alles met behulp van die elektroniese beheerstelsel.

Die beheerstelsel gebruik die inligting, verkry vanaf die verskillende sensore, soos byvoorbeeld die lasselle in die verskillende toue en inklinasie sensors, om die verskillende wenaste te beheer en om 'n stabiele oprigting te verseker. Hierdie gedeelte van die oprigtingproses gebeur automaties sonder enige menslike inmenging behalwe om toesig te hou en die proses te onderbreek in geval van nood. Sodra die toring regop is, word die toring deur middel van dom- 
kragte laat sak op sy fondasie, die permanente ankertoue vasgemaak aan hulle ankers en die skarniermeganisme verwyder. Werkers kan nou al die ander tydelike toue, ankers en ander toerusting verwyder en aan beweeg na die volgende toringposisie.

\section{'n Studie van die Basiese Oprigtings- metode}

Die mees basiese opstelling vir die oprigting van 'n hangtoring word gewys in Figuur 4, en hier ondersoek. Dit behels die plasing van die toring in sy korrekte horisontale posisie met ondersteuningspunte wat die bokant van die nutspaal voorstel by koördinate $(10,-0.5,14)$ en $(10,0.5,14)$. Een van die eerste doelwitte is om die minimum hoogte van die nutspaal te bepaal sodat geen onderdeel van die toring 'n maksimum van $80 \%$ (SANS, 2017) van sy werkkapasiteit oorskry tydens die oprigtingsproses nie, asook die bepaling van kragte wat op die toringfondasie, nutspaal en toue uitgeoefen word. 'n Sagteware program 'PLS Tower' is gebruik om die tipe 520B kabelgesteunde V-toring se oprigting vanaf 'n afhanklike $1^{\circ}$ hoek relatief tot die horisonvlak te analiseer. Al die hoof en versterkende onderdele van die toring word gemodeleer en met toepassing van die korrekte kragte kan 'PLS Tower' die gebruiker 'n oorsig gee wat die druk- of trekkragte in elke onderdeel van die toring is, uitgedruk as 'n persentasie van die onderdeel se kapasiteit. Die beginposisie van $1^{\circ}$, relatief tot die horisonvlak, is om vir klein defleksies in die ondersteuningstoue ens. voorsiening te maak wat die uiteindelike beginposisie na aan die verlangde horisonvlak bring. Vir die modelering van die tipe 520B kabelgesteunde $\mathrm{V}$-toring is die volgende parameters gebruik:

$$
\begin{aligned}
& \text { - Toringhoogte = } 39.65 \mathrm{~m} \text { (die hoogste } \\
& \text { in die 520B reeks) } \\
& \text { - } \text { Geleier vashegtingshoogte }=33.0 \mathrm{~m} \\
& \text { - } \text { Toringmassa }=7960 \mathrm{~kg}
\end{aligned}
$$

In die aanvanklike eerste ontwerp is die nutspaal gemodeleer deur twee vaste punte, $14 \mathrm{~m}$ bokant die grond en 10 $\mathrm{m}$ weg vanaf die toringfondasie. Die waardes van $14 \mathrm{~m}$ en $10 \mathrm{~m}$ is na willekeur gekies, gebaseer op konstruksiepraktyke en ondervinding opgedoen tydens nood herstelprojekte. Hierdie veereenvoudigde modelering van die nutspaal is voldoende aangesien die eerste doelwit slegs moet bepaal wat die minimum hoogte van sodanige nutspaal behoort te wees, sonder dat enige toringonderdeel sy 80 \% werkskapasiteit sal oorskry. Bykomend tot die massa van die toring is daar verder voorsiening gemaak vir die massa van die hardeware en isolators wat saam met die toring, in een aksie opgelig kan word (voorgestel as C1, C2 en C3 in

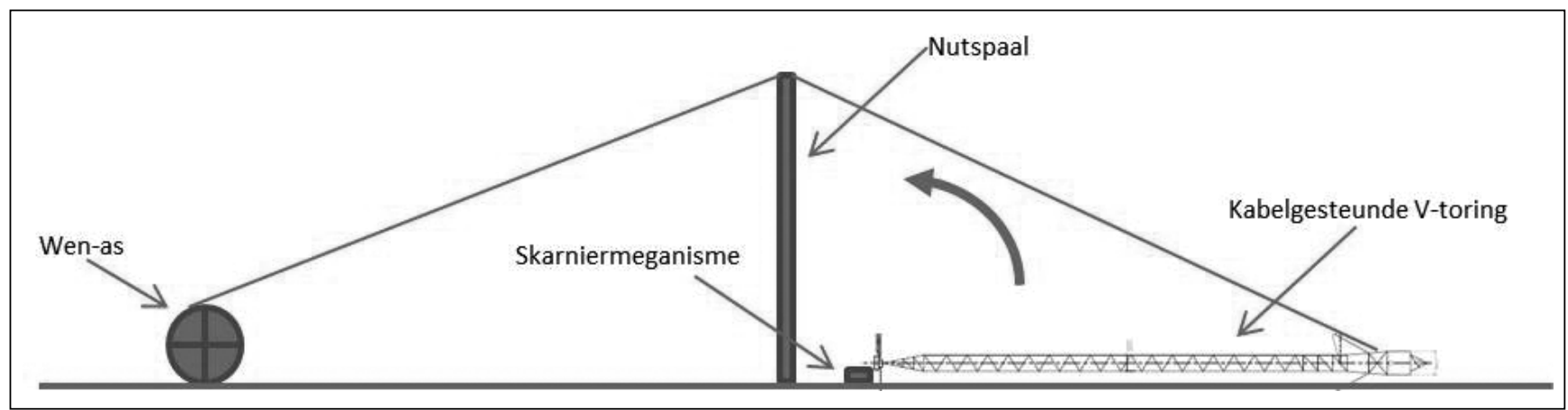

FIGUUR 2: Sy-aansig van die toring, nutspaal en wen-as in rusposisie voor oprigting.

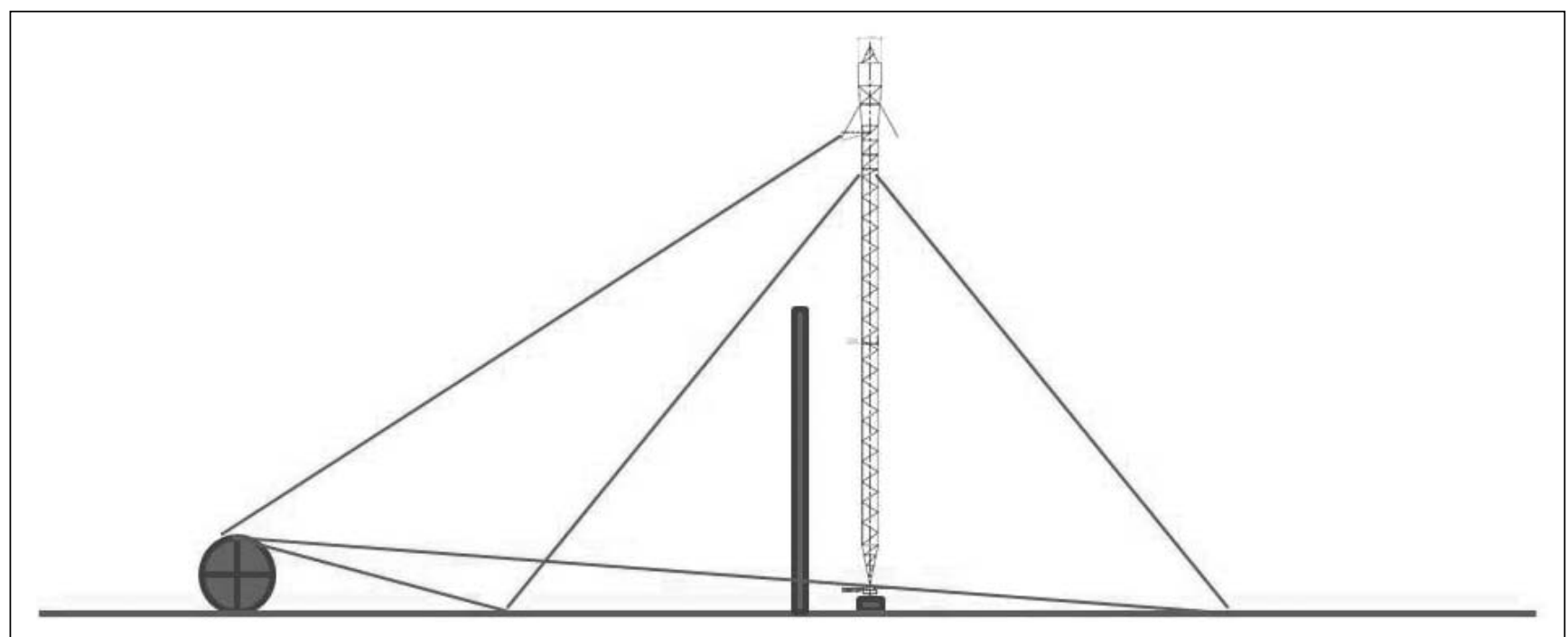

FIGUUR 3: Die finale posisie van die toring na oprigting 


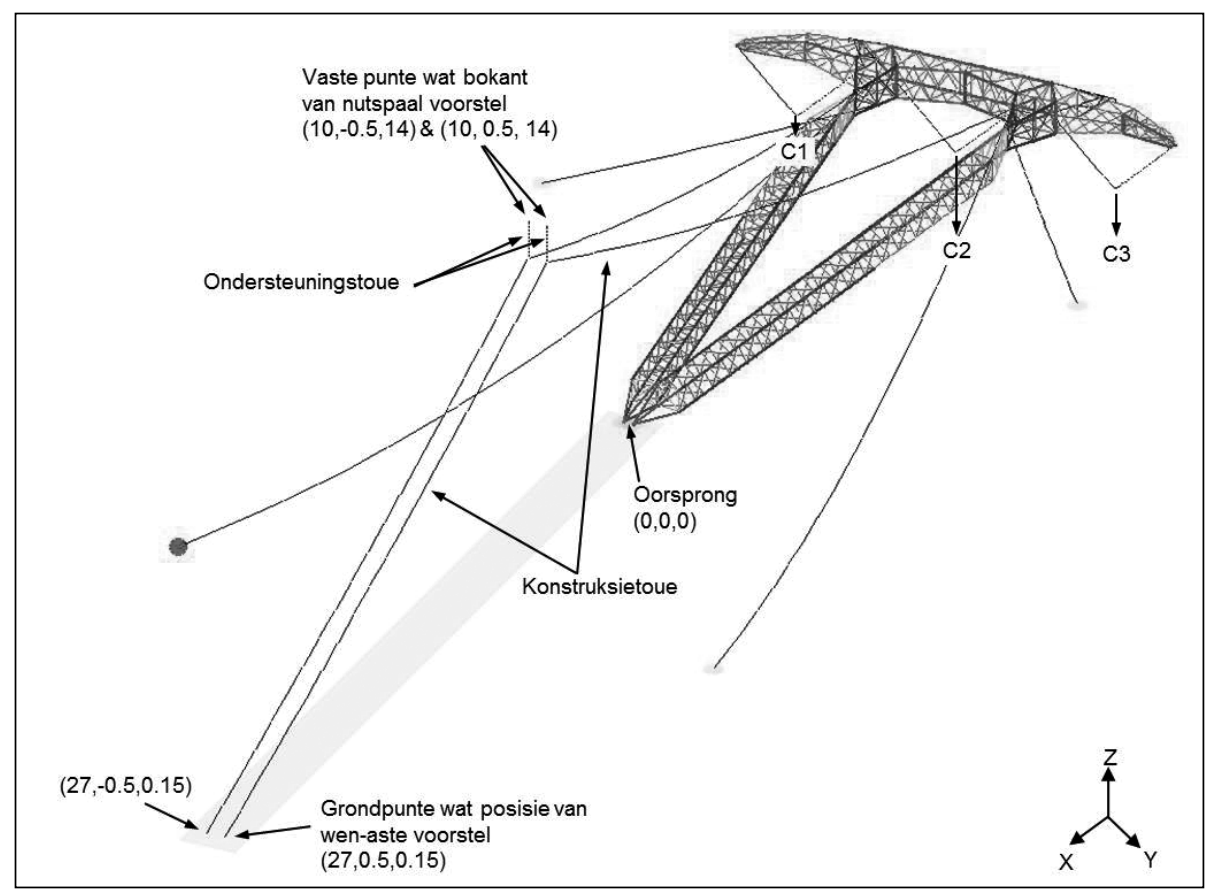

FIGUUR 4: Die basiese opstelling in 'PLS Tower' van die tipe 520B toring voor oprigting.

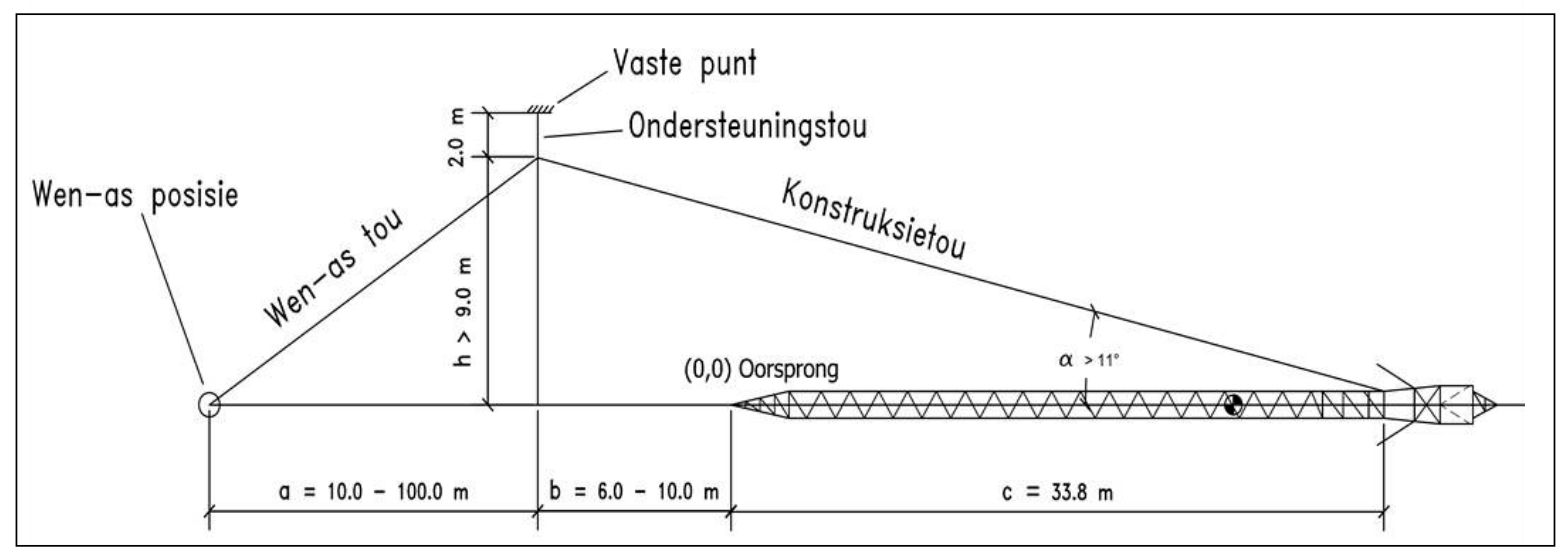

FIGUUR 5: Grensvoorwaardes vir gebruik van nutspaal tydens oprigting van die tipe 520B kabelgesteunde V-toring.

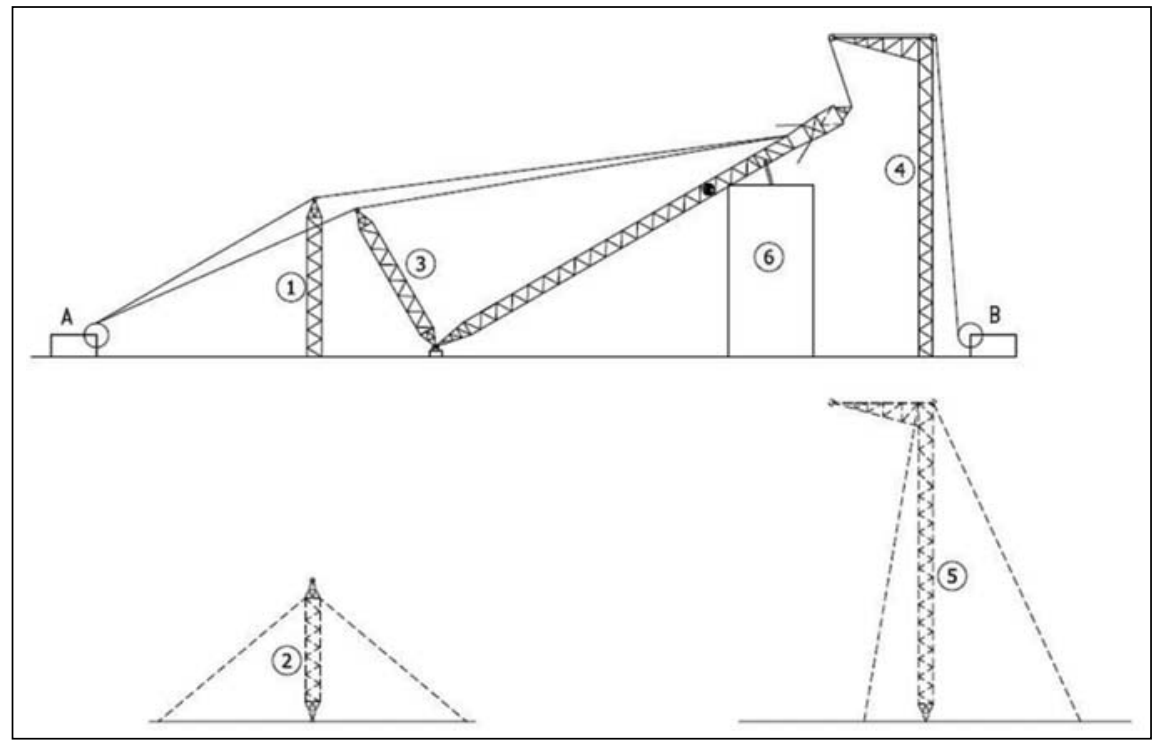

FIGUUR 6: Ses verskillende oprigtingskonfigurasies wat met mekaar vergelyk is. 
Figuur 4). Vir hierdie aanvanklike konfigurasie van die nutspaal was die doelwit om die minimum waarde van hoek $\alpha$ te bepaal soos gesien in Figuur 5 .

Daar moet in ag geneem word dat daar talle moontlike konfigurasies en posisies bestaan vir die gebruik van 'n nutspaal en dat die voorstelling in Figuur 5 slegs as 'n basiese vertrekpunt gebruik is. Die 'PLS Tower' modelering en analise het getoon dat, indien hoek $\alpha$ kleiner as $11^{\circ}$ is, 'n aantal onderdele in die toring oorlaai word, a.g.v. die toename in die longitudinale of horisontale kragte, wat deur die oprigtingsproses geinduseer word.

In 'n onlangse studie deur die huidige outeurs (Jacobs et al., 2020) is vier verskillende nutspaal-konfigurasies, asook twee variasies van die vier, bestudeer. Hierdie ses verskillende konfigurasies kan in Figuur 6 gesien word waar hulle almal oormekaar gelê is sodat hulle met mekaar vergelyk kan word.

In Figuur 6 word die tipe 520B kabelgesteunde V-toring in 'n gedeeltelike oprigtingsposisie getoon. Opsie (1) toon die basiese, aanvanklike konfigurasie, wat skematies in Figuur 4 en 5 aangedui word. Konfigurasie (1) stel 'n self-staande nutspaal voor wat op 'n kort afstand vanaf die basis en fondasie van die toring geplaas is. Konfigurasie (2) is soortgelyk aan die vorige konfigurasie behalwe dat toue die nutspaal in posisie hou a.g.v. sy tapse onderkant. Opsie (3) staan ook bekend as die kantel ("tilt-up") metode (IEEE, 2009) van oprigting waar die nutspaal se basis aan die onderkant van die toring geheg word. In opsie (4) word 'n self ondersteunende nutspaal aan die teenoorstaande kant van die toring geplaas waar die eerste wen-as die toring slegs gedeeltelik kan oplig totdat ' $n$ tweede wen-as die oprigtingsproses kan voortsit. Opsie (5) is 'n variasie van opsie (4) waar toue weereens gebruik word om die nutspaal te ondersteun. In die laaste konfigurasie (6) word gebruik gemaak van 'n lugkussing om die toring gedeeltelik op te lig waarna 'n wen-as die oprigtingsproses voortsit.

Die studie deur (Jacobs et al., 2020) het getoon dat die beste konfigurasie opsie (3) is met opsie (6) in 'n nabye tweede plek. Opsie (3) is daarom verder in (Jacobs et al., 2020) bestudeer deur onder andere 'n geskikte nutspaalontwerp en wen-as grootte te vind.

\section{Nutspaal en Skarniermeganisme}

Die nutspaal is ' $n$ sleutelkomponent in die oprigtingsproses en moet sterk genoeg wees om die kragte wat daarop uitgeoefen word, te kan weerstaan en terselfdertyd maklik genoeg rond geskuif kan word. Die massa van die nutspaal is daarom 'n belangrike oorwegingspunt. Verder is dit nodig vir die toring om van sy aanvanklike horisontale posisie tot finale vertikale posisie te kan roteer. 'n Geskikte skarniermeganisme is dus ook nodig. Vir die bepaling van die kragte wat op die toring inwerk asook die reaksiekragte op die nutspaal en skarniermeganisme is die sagteware program 'PLS Tower' gebruik om die oprigtingsproses te simuleer in intervalle van $5^{\circ}$ van die horisontale oriëntasie $\left(0^{\circ}\right)$ tot vertikale oriëntasie $\left(90^{\circ}\right)$. Aangesien die verwagte oprigtingstempo stadig sal wees as gevolg van die relatiewe lae snelheid van die wen-aste wat gebruik word, asook die moontlike gebruik van katrolle, is die voorgestelde statiese analise van die simulasie relevant en aanvaarbaar. 'n Soortgelyke benadering is gevolg deur Van Zyl et al (2006), waar die analise van 'n roterende struktuur geëvalueer was in intervalle van $10^{\circ}$.

Die resultate kan in Grafiek 1 waargeneem word waar die longitudinale-rigting parallel is met die oorhoofse lyn. Let daarop dat die kragte, aangetoon in Grafiek 1, bereken is met die kortste nutspaal van $9 \mathrm{~m}$ lank wat gebruik kan word, sodat hoek $\alpha$ nie kleiner as $11^{\circ}$ moet wees nie (sien

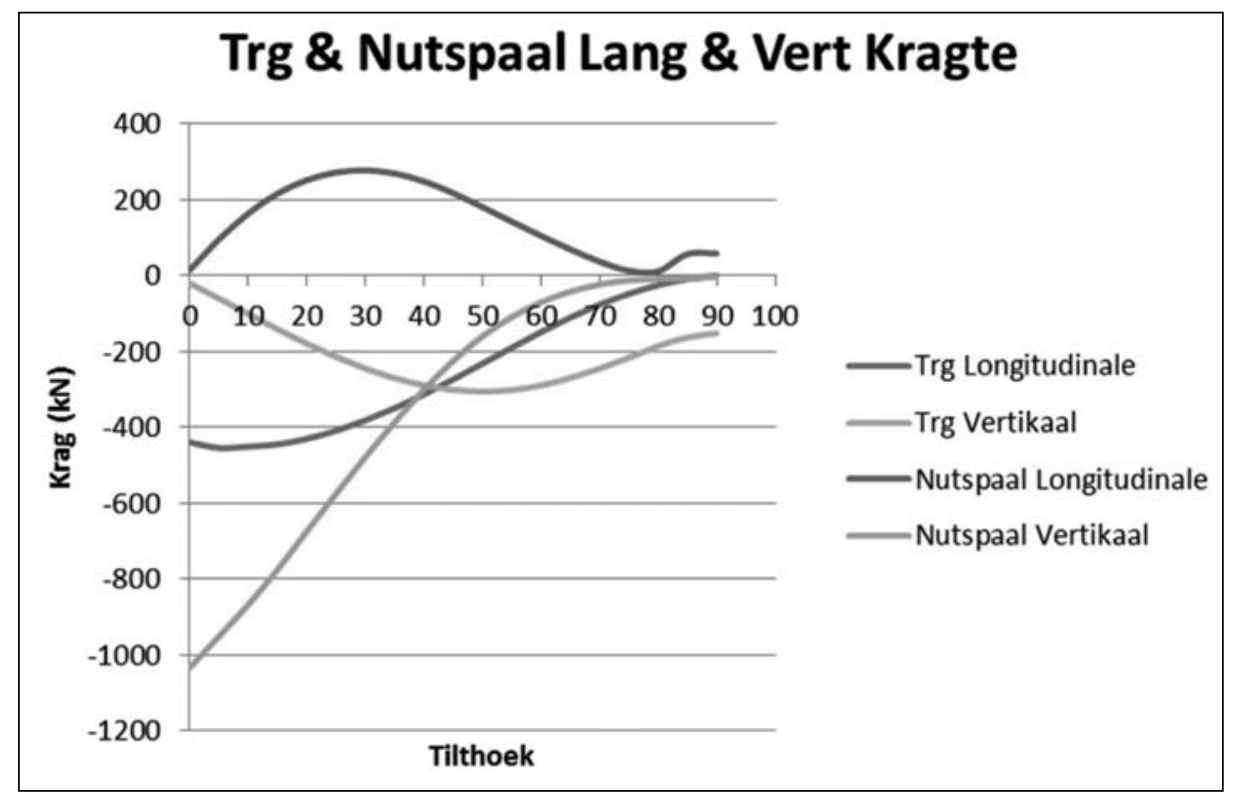

GRAFIEK 1: Vertikale en longitudinale kragte teenoor tilthoek van die toring (Trg) en nutspaal soos bereken met 'PLS Tower'. 
Figuur 5). Hierdie korste nutspaal oefen dan ook die grootste kragte uit aangesien sy hefvoordeel die kleinste is.

Vir die ontwerp van die nutspaal asook dié van die skarniermeganisme is die resultate soos in Grafiek 1 weergegee gebruik. In beide gevalle bestaan die ontwerpe uit 'n raamwerk wat van standaard staalprofiele (Construction, 2010) gebruik maak. Dit is duidelik uit die resultate van Grafiek 1 dat die grootste kragte voorkom by die aanvanklike hoek van $0^{\circ}$ en wel in die nutspaal in 'n vertikale afwaartse rigting en in die toring in die longitudinale rigting. Soortgelyke resultate is deur (Wood, 2007) verkry. Daarom is die steun van die skarniermeganisme om die piek longitudinale kragte wat deur die toring uitgeoefen word te kan weerstaan, van uiterste belang. 'n Moontlike skarniermeganismeontwerp, bestaande uit 'n driehoekvormige raamwerk en wat 'n as, wat vertikaal open-af kan beweeg, en wat deur domkragte in posisie gehou word, kan in Figuur 7 gesien word. Die toring roteer om 'n as waar die toring aan die as gekoppel word deur middel van verwyderbare klampe aan die onderkant van die toringbene. Sodra die toring regop staan word dit laat sak deur middel van die domkragte tot op die fondasie. Daarna kan die driehoekraam gedeeltelik uitmekaar gehaal en verwyder word om na die volgende toringposisie geneem te word.

\section{Die Lugkussingkonsep}

Lugkussings kom in verskillende vorme en groottes voor en word in verskillende toepassings gebruik om byvoorbeeld swaar masjinerie rond te skuif, waar van die effektiwiteit van die lae weerstand lug-laer gebruik gemaak word. 'n Voorbeeld van so 'n sisteem is deur Lisowski en Filo (Lisoowski, Filo., 2011) ondersoek. Nog 'n variasie en gebruik van die lugkussingbeginsel is die welbekende 'hovercraft'. Ander toepassings van lugkussings staan bekend as opligkussings waar lug in 'n rekbare houer, gewoonlik van rubber vervaardig, met 'n sirkelvormige of vierkantige vorm gepomp word. Afhangende van die grootte en sterkte van die kussing kan lug onder hoë druk met behulp van 'n kompressor, of onder laedruk deur middel van 'n waaier ingeblaas word. 'n Variasie van laasgenoemde sisteem, wat van'n groot oppervlakte en lae druk gebruik maak om iets op te lig, kom in die vermaaklikheidsindustrie voor as springkussings (jumping castles), water glybane asook 'ruimtevaart- vuurpyle'. Figuur 8 toon 'n voorbeeld van ' $n$ waterglybaan.

Dieselfde konsep van lae druk lug wat in 'n geskikte driehoekige kussing ingeblaas word kan gebruik word om die tipe 520B kabelgesteunde V-toring op te lig en kan gesien word in Figuur 9.

Die oprigtingsproses met behulp van die driehoekvormige lugkussing begin deur die kussing onder die toring op 'n geskikte voorbereide terrein wat skoon is van skerp voorwerpe te plaas. Lae druk lugblasers word nou om die lugkussing in vooraf bepaalde posisies geplaas en aan doelgemaakte inlaatbuise gekoppel. Die driehoekvormige lugkussing word aan sy binnekant versterk deur afskortings, wat die kussing verdeel in aparte kompartemente, en wat sal voorkom dat die lugkussing katestrofies intuimel indien eninge kompartement beskadig sou word. Afhangend van die grootte van die lugkussing, is dit in beginsel moontlik om die toring hoog genoeg te lig dat die

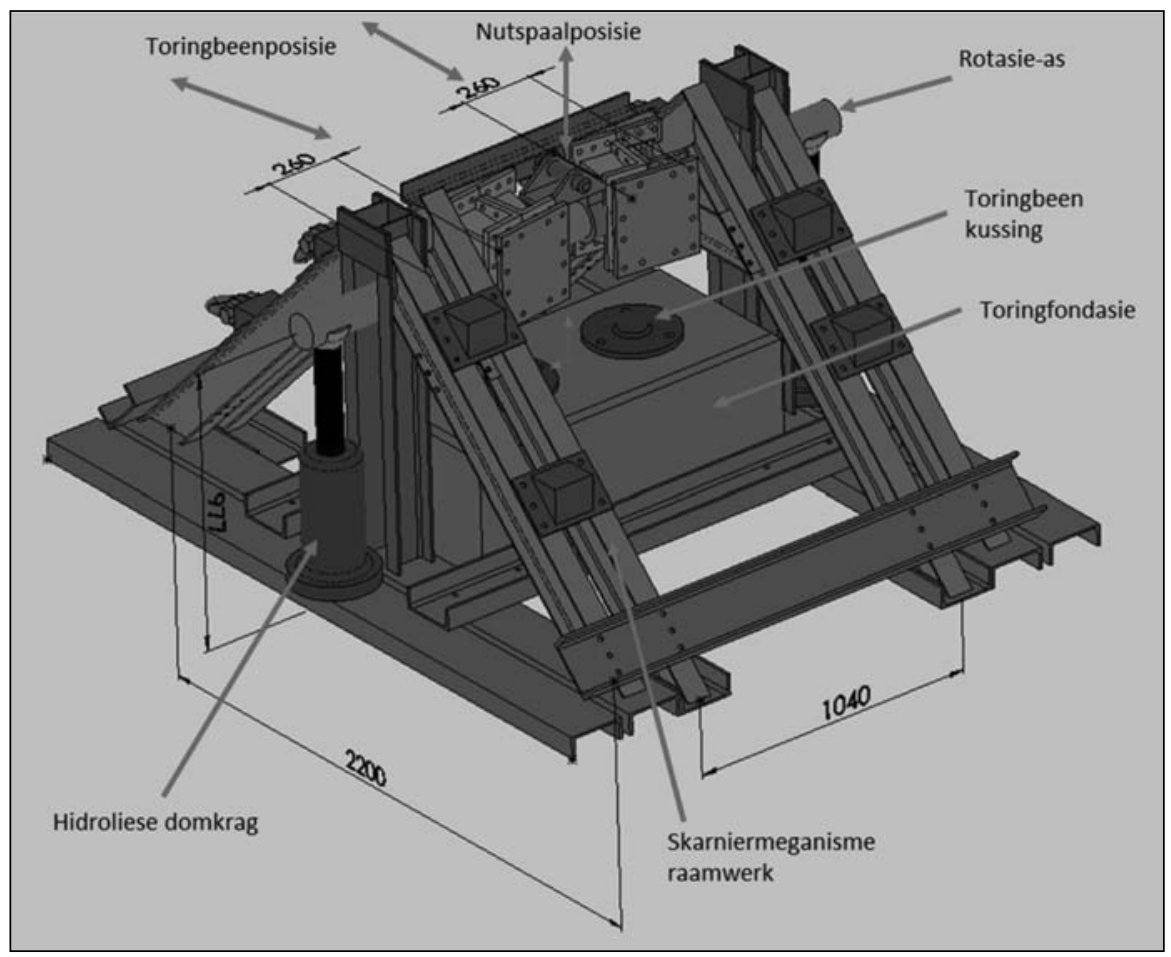

FIGUUR 7: Konsepontwerp van 'n driehoekvormige skarniermeganisme raamwerk. 


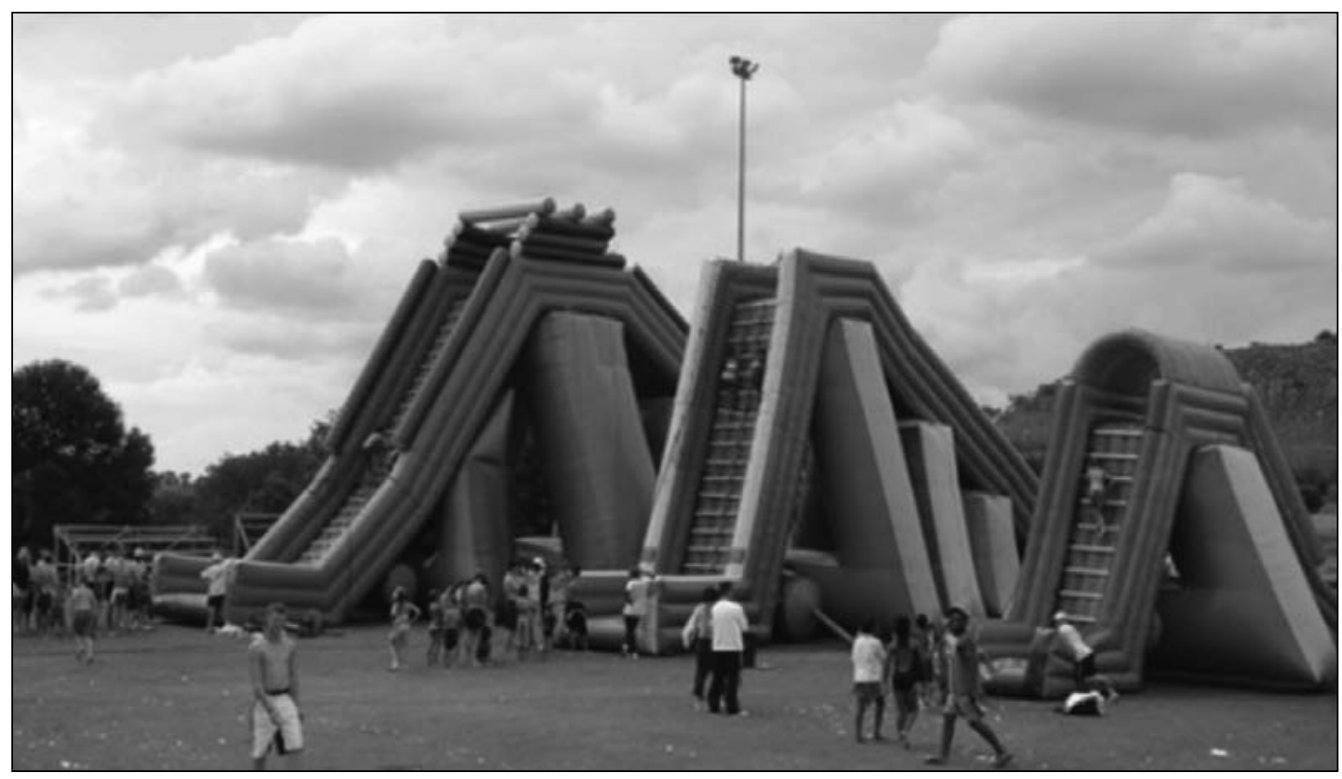

FIGUUR 8: Voorbeeld van 'n laedruk lugondersteunde waterglybaan.

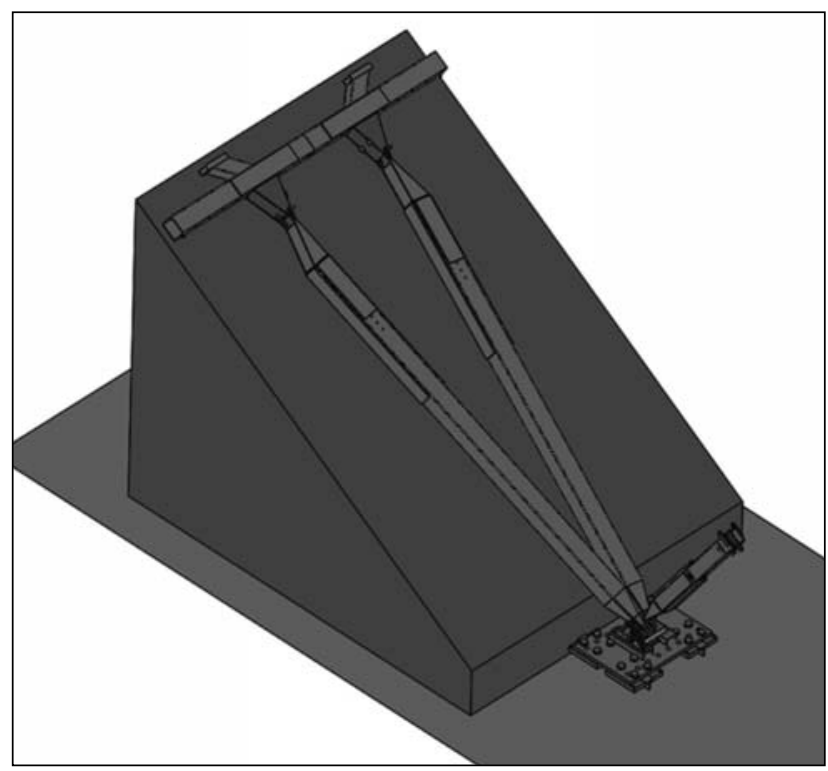

FIGUUR 9: Konsepontwerp van 'n lugkussing om die tipe 520B kabelgesteunde V-toring op te lig.

gebruik van die nutspaal geëlimineer kan word. Na die aanvanklike lugkussingfase word die oprigtingsproses van die kabelgesteunde V-toring voltooi deur middel van enkele wen-aste.

\section{Die Potensiele Ekonomiese Vat- baarheid van die Alternatiewe Op- rigtingsmetode}

Die alternatiewe 'tilt-up' oprigtingsmetode wat hier voorgestel word vir die gebruik in die konstruksie van oorhoofse kraglyne is al toegepas in die oprigting van windturbines. In 'n studie gedoen deur (Ganser et al., 2014) is dit bevind dat die 'tilt-up' metode van oprigting van klein residensiële windturbines, baie laer kostes tot gevolg het in vergelyking met die gebruik van mobiele hyskrane.
In nog 'n studie deur (Orrell, 2017) wat fokus op die instaleringskoste van windturbines, is daar bevind dat minimale installasiekoste moontlik is deur gebruik te maak van die 'tilt-up' metode, wat baie min arbeid en gereedskap verg.

Aangesien die werklike koste wat kontrakteurs aangaan om oorhoofse kraglyne te bou moeilik bekombaar is, deels as gevolg van die hoogs kompeterende mark waarin hulle werksaam is, kan slegs beperkte kapitale koste wat aangegaan is vergelyk word. Indien die koste van 'n nuwe 90 ton mobiele hyskraan, wat die minimum grootte is om die tipe 520B kabelgesteunde V-toring op te hys, vergelyk word met die koste van 'n wen-as en nutspaal stelsel, is gevind dat laasgenoemde se koste slegs $25 \%$ van die kapitale koste van 'n 90 ton hyskraan is.

Die toerus of 'dressing'(Badenhorst, Marais, 2005) van 'n toring verwys na die aanhegting van die isolatore en hardeware aan die toring wat benodig word om die geleiers te ondersteun tussen die verskillende torings. Hierdie toerus van die toring word normaalweg as 'n aparte stap gedoen nadat die toringoprigtingstaak voltooi is. Met die voorgestelde alternatiewe oprigtingsmetode kan die toerus van hardeware en isolatore op die grond geskied voordat die toring opgehys word en kan die volledige toring met hardeware en al in een aksie opgehys word. Sodoende kan verdere koste bespaar word aangesien die addisionele proses om die toring toe te rus geëlimineer word.

'n Verdere tydbesparingsfaktor is die relatiewe eenvoud waarmee die wen-as en nutspaal vervoer kan word tussen die verskillende toringposisies. In vergelyking met 'n mobiele hyskraan wat dikwels beperk is in sy beweging tussen torings as gevolg van padtoestande en terrein, en waar die balanseergewigte van die hyskraan per geleentheid verwyder moet word om beter mobiliteit te verseker, is vervoervereistes van die alternatiewe metode, 
hier voorgestel, baie makliker. Verder kan die wen-as en nutspaaltoerusting bekostigbaar gedupliseer word sodat ' $n$ aantal torings in parallel met mekaar opgerig kan word.

Daar word voorsien dat die lugkussingkonsep van oprigting selfs meer mobiel en van minder toerusting afhanklik sal wees en sodoende verdere kostebesparings teweeg behoort te bring in vergeleke met die wen-as en nutspaal proses.

\section{Gevolgtrekking}

Daar is 'n duidelike behoefte om meer ekonomiese metodes te ondersoek om oorhoofse kraglynkonstruksie goedkoper te maak. Die gebruik van wen-aste en nutspale vir die oprigting van die tipe 520B kabelgesteunde V-toring is tot op datum nog nie geïmplementeer nie en is hier ondersoek as ' $n$ alternatief. Ses verskillende oprigtingskonfigurasies is met mekaar vergelyk in 'n vorige ondersoek en die mees vatbare opsie is nommer (3) wanneer die nutspaal aan die voet van die toring geplaas word, gekoppel aan dieselfde skarniermeganisme, soos geillustreer in Figuur 6. 'n Onkonvensionele konsep, waar 'n lugkussing gebruik word vir die aanvanklike oprigtingstadium en waar die nutspaal geëlimineer word, sal verder bestudeer word in ' $n$ opvolgstudie.

Beduidende koste- en tydbesparings kan bewerkstellig word met die gebruik van hierdie wen-as en nutspaal alternatiewe oprigtingsmetode wanneer dit vergelyk word met die ooreenstemmende kostes van mobiele hyskrane wat gewoonlik vir die oprigting van kabelgesteunde V-torings gebruik word. Hierdie alternatiewe konsep kan ook geskaal word vir byvoorbeeld die oprigting van soorgelyke kabelgesteunde V-torings in die $765 \mathrm{kV}$ hoogspanningsvlak oorhoofse lyne. Laasgenoemde oorhoofse kraglyne word algemeen in Suid-Afrika gebruik. Dienooreenkomstig kan die alternatiewe oprigtingsmetode ook vir laer spanningskraglyne gebruik word waar toegang vir toerusting soos mobiele hyskrane moeilik is.

\section{Verwysings}

Badenhorst B, Marais P. 2005. Construction. In: Bisnath S, Britten A, Cretchley D, Muftic D, Pillay T \& Vajeth R (Eds.). The Planning, Design and Construction of Overhead Power Lines. 2 Theunis Street, Bedford Gardens, Johannesburg: Crown Publications cc:677-722.

Eskom. Eskom Holdings. 2016. Eskom Holdings Corporate Plan Financial years 2016/17-2020/21 [Online]. Available from: [Accessed].

IEEE Guide to the Assembly and Erection of Metal Transmission Structures. 2009. (pp. 44). United States of America: IEEE.

Jacobs B, Desai D, Du Plessis L, 2020. A Critical Review of Alternative Erection Methods for Overhead Line Towers. International Journal of Engineering Research and Technology, 13(7), 2020:5.

Kiessling F, Nefzger P, Nolasco JF, Kaintzyk U. 2003. Overhead Power Lines, Planning, Design, Construction. Berlin: Springer.

Lisowski E, Filo G. Pressure control in air cushions of the mobile platform. Journal of KONES Powertrain and Transport, 18(2):10.

OrrellAC, PoehlmanEA.2017. BenchmarkingU.S.SmallWindCosts, WiththeDistributed Wind Taxonomy. United States of America: United States Department of Energy.

South African Institute of Steel Construction. 2010. Southern African Steel Construction Handbook. 7 ed. Cape Town.

South African National Standards. 2017. 10280-1 Overhead power lines for conditions prevailing in South Africa. Part 1: Safety (2.1 ed., pp. 63). Pretoria: South African Bureau of Standards.

Van ZyI PJA, Burger NDI, De Wet PR. 2006. Verification of a Finite Element Model of a Rotating Tippler Structure by Means of Strain Gauge Measurements. R \& D Journal of the South African Institution of Mechanical Engineering, 22(3):1-15.

Wolkiewicz D, Ganser H, Samaroo MA, Mamayek SB. 2014. Design Framework for Comparing Wind Turbine Tower Erection Methods (Major Qualifying Projects). Worcester Polytechnic Institute.

Wood DH. 2007. A Simple Force Analysis for the Raising and Lowering of a Small Wind Turbine and Tower. Wind Engineering, 31(3):211-216. 